\title{
ДОСЛІДЖЕННЯ ЖИРНОКИСЛОТНОГО СКЛАДУ ТРАВИ МИКОЛАЙЧИКІВ плоских
}

\author{
К. В. Гнатойко, А. Р. Грицик \\ Івано-Франківський національний медичний університет \\ dowbeniuk@ukr.net
}

ІНФОРМАЦІЯ

Надійшла до редакції / Received: 07.12 .2021

Після доопрацювання / Revised: 16.12.2021

Прийнято до друку / Accepted: 20.12.2021

\section{Ключові слова:}

миколайчики плоскі;

жирні кислоти;

газова хроматограсрія;

лікарські рослини.

\begin{abstract}
АНОТАЦІЯ
Мета роботи. Вивчити якісний і кількісний вміст жирних кислот у траві миколайчиків плоских (Eryngium planum L.).

Матеріали і методи. Об'єкт дослідження - трава миколайчиків плоских, заготовлена в с. Підлужжя Тисменицького району Івано-Франківської області в 2021 р. Якісний і кількісний вміст жирних кислот визначали методом газової хромато-мас-спектрометрії на приладі Agilent 6890N/5973inert (Agilent technologies, USA).

Результати й обговорення. У траві миколайчиків плоских виявили та ідентифікувати 7 жирних кислот (2 ненасичені та 5 насичених). Кількісно переважають а-ліноленова, олеїнова та пентадеканова кислоти (37,6 \%, 29,5 \% та 22,1 \% відповідно). Також було виявлено стеаринову, бегенову, трикозанову, лігноцеринову кислоти, загальна сума яких складає 10,8 \%.

Висновки. В ході дослідження було встановлено якісний склад та кількісний вміст жирних кислот у траві миколайчиків плоских. Загалом ідентифріковано 7 жирних кислот, серед яких значно переважають а-ліноленова, олеїнова та пентадеканова кислоти.
\end{abstract}

Вступ. Миколайчики плоскі (Eryngium planum L.) - багаторічна рослина роду Миколайчики (Eryngium) підродини - Saniculoideae родини Селерові (Зонтичні) - Apiaceae (Umbelliferae) [1].

Згідно із базою даних «The Plant List» рід Миколайчики включає більше ніж 250 представників, які поширені в помірному кліматичному поясі Північної та Південної півкуль. Більшість видів є дикорослими, проте в деяких місцевостях їх успішно культивують $[2,3]$. Миколайчики плоскі $€$ найпоширенішим дикорослим видом на території України [4].

Багато видів даного роду є харчовими та декоративними рослинами, деякі види застосувують у народній медицині [5]. Надземні та підземні органи миколайчиків плоских вміщують велику кількість біологічно активних речовин, зокрема ефрірної олії. Основ- ними компонентами листків та стебла $€$ моноциклічні монотерпени (лімонен, $\alpha$-, $\beta$-пінен) та сесквітерпени. Ефірна олія коренів здебільшого вміщує (Z)-оралькаринол та 2,3,4-триметилбензальдегід [6]. Трава миколайчиків плоских вміщує такі фрлавоноїди, як рутин, кемпферол, ізокверцетин, лютеолін, апігенін [7]; листя вміщує такі вуглеводи, як фрруктоза, глюкоза і сахароза; органічні кислоти: яблучна, лимонна, малонова, гліколева та щавлева; тритерпеноїди: ерингіумгенін A, A, B, F, G, H, ерингінол B; френолкарбонові кислоти та їх похідні: хлорогенова та розмаринова; фрлавоноїди: кверцетин, кемпферол, 3,7-дирамнозид кемпферолу [8, 9].

Різноманітний хімічний склад видів роду Миколайчики зумовлює широкий спектр їх фрармакологічної активності. Зокрема, Monika Derda та інші науковці

ISSN 2312-0967. Pharmaceutical review. 2021. № 4 
Познанського медичного університету дослідили амебіцидну активність миколайчиків плоских проти Acanthamoeba castellanii [10].

Миколайчики плоскі використовують при лікуванні запальних стоматологічних захворювань, таких як пародонтит, карієс і зубний біль [11].

Науковцями зі спілки познанських університетів у 2015 році було доведено вплив миколайчиків плоских на поліпшення довгострокової пам'яті на моделі скополамінового розладу пам'яті [12].

Завдяки синергічному ефекту урсолової кислоти, рутину, хлорогенової та розмаринової кислот, проявляється фрармакологічний потенціал для лікування запалення та діабету. Екстракти миколайчиків плоских демонструють інгібування фрерментів до лікування цукрового діабету 2 типу [7].

Матеріали і методи. Наважку рослинної сировини (0,1-0,2 г) розтертої до порошкоподібного стану поміщали в скляну віалу та здійснювали метилювання за допомогою розчину натрію метилату в метанолі 2 моль/л. Як внутрішній стандарт використовували розчин тридекану. Суміш ретельно перемішували та поміщали на ультразвукову баню при температурі $80{ }^{\circ} \mathrm{C}$. Метилювання жирних кислот проводили впродовж 2 годин. Отримані метилові ефріри жирних кислот екстрагували гексаном.

Хроматограсрічне розділення проводили на газовій хромато-мас-спектрометричній системі Agilent 6890N/5973inert (Agilent technologies, USA), колонка капілярна HP-5ms $(30 \mathrm{~m} \times 0,25 \mathrm{~mm} \times 0,25 \mathrm{mkm}$, Agilent technologies, USA), температура випаровувача $250{ }^{\circ} \mathrm{C}$, температура інтерфейсу - $280{ }^{\circ} \mathrm{C}$. Розділення проводили в режимі програмування температури - початкову температуру $150{ }^{\circ} \mathrm{C}$ витримували впродовж 4 хв піднімали 3 градієнтом $5{ }^{\circ} \mathrm{C} /$ хв до $300{ }^{\circ} \mathrm{C}$. Кінцеву температуру витримували впродовж 6 хв. Пробу об'ємом 1 мкл вводили в режимі поділу потоку 1:50. Детектування проводили в режимі SCAN у діапазоні (38-400 m/z). Швидкість потоку газу-носія че- рез колонку - 1,0 мл/хв. Ідентифрікацію метилових есрірів жирних кислот здійснювали за часом утримання піків порівняно зі стандартною сумішшю. Розрахунок складу метилових есрірів проводили методом внутрішньої нормалізації за загальноприйнятою методикою.

Результати й обговорення. Результати дослідження методом газової хроматографрії якісного складу і кількісного вмісту жирних кислот у траві миколайчиків плоских наведено в таблиці і на рисунку.

У траві миколайчиків плоских визначено 24 жирні кислоти, 7 з яких ідентиоріковано (2 ненасичені та 5 насичених). Загальний вміст суми жирних кислот - 14 477,4 мкг/г. Серед усіх жирних кислот найбільшу концентрацію визначено для $\alpha$-ліноленової кислоти (37,6 \%), олеїнової кислоти (29,5\%) та пентадеканової кислоти (22,1 \%). Також у траві миколайчиків плоских було виявлено стеаринову, бегенову, трикозанову, лігноцеринову, гептадеканову та гептакозанову кислоти, загальна сума яких складає 10,8 \% від усіх ідентифрікованих жирних кислот.

а-ліноленова кислота належить до незамінних жирних кислот, які повинні надходити з їжею для нормальної життєдіяльності організму людини, і належать до класу омега-3-ненасичених жирних кислот. $\alpha$-ліноленова кислота знижує ризик серцево-судинних захворювань, пов'язаних 3 аритміями, тромбозом, підвищеним рівнем тригліцеридів, атеросклерозом, високим рівнем артеріального тиску та ін. Недостатня кількість $\alpha$-ліноленової кислоти може спровокувати патологічні стани різних органів чи систем людського організму [13].

Олеїнова кислота, також відома як омега-9ненасичена жирна кислота, здатна знижувати рівень холестерину в крові та перешкоджати осіданню холестеринових бляшок на стінки судин, знижуючи таким чином ризик розвитку атеросклерозу [14].

\section{Таблиця}

Якісний склад і кількісний вміст ідентифрікованих жирних кислот у траві миколайчиків плоских

\begin{tabular}{|c|c|c|c|c|c|}
\hline \multirow{2}{*}{$\begin{array}{l}\text { № } \\
\text { 3/ח }\end{array}$} & \multirow{2}{*}{ Назва жирної кислоти } & \multirow{2}{*}{ Хімічна фрормула } & \multirow{2}{*}{ Час утримання } & \multicolumn{2}{|c|}{ Вміст } \\
\hline & & & & Мкг/г & $\% *$ \\
\hline 1 & Пентадеканова & $\mathrm{C}_{17} \mathrm{H}_{34} \mathrm{O}_{2}$ & 15,03 & 3206,4 & 22,1 \\
\hline 2 & а-ліноленова & $\mathrm{C}_{18} \mathrm{H}_{32} \mathrm{O}_{2}$ & 18,93 & 5441,0 & 37,6 \\
\hline 3 & Олеїнова & $\mathrm{C}_{18} \mathrm{H}_{34} \mathrm{O}_{2}$ & 19,08 & 4276,7 & 29,5 \\
\hline 4 & Стеаринова & $\mathrm{C}_{18} \mathrm{H}_{36} \mathrm{O}_{2}$ & 19,62 & 536,5 & 3,7 \\
\hline 5 & Бегенова & $\mathrm{C}_{22} \mathrm{H}_{44} \mathrm{O}_{2}$ & 27,89 & 315,4 & 2,3 \\
\hline 6 & Трикозанова & $\mathrm{C}_{23} \mathrm{H}_{46} \mathrm{O}_{2}$ & 29,81 & 222,8 & 1,5 \\
\hline \multirow[t]{2}{*}{7} & Лігноцеринова & $\mathrm{C}_{24} \mathrm{H}_{48} \mathrm{O}_{2}$ & 31,59 & 478,6 & 3,3 \\
\hline & \multicolumn{3}{|l|}{ Загальний вміст } & 14477,4 & \\
\hline
\end{tabular}

Примітка. * - відносно загальної кількості ідентифрікованих жирних кислот.

ISSN 2312-0967. Фармацевтичний часопис. 2021. № 4 
Abundance

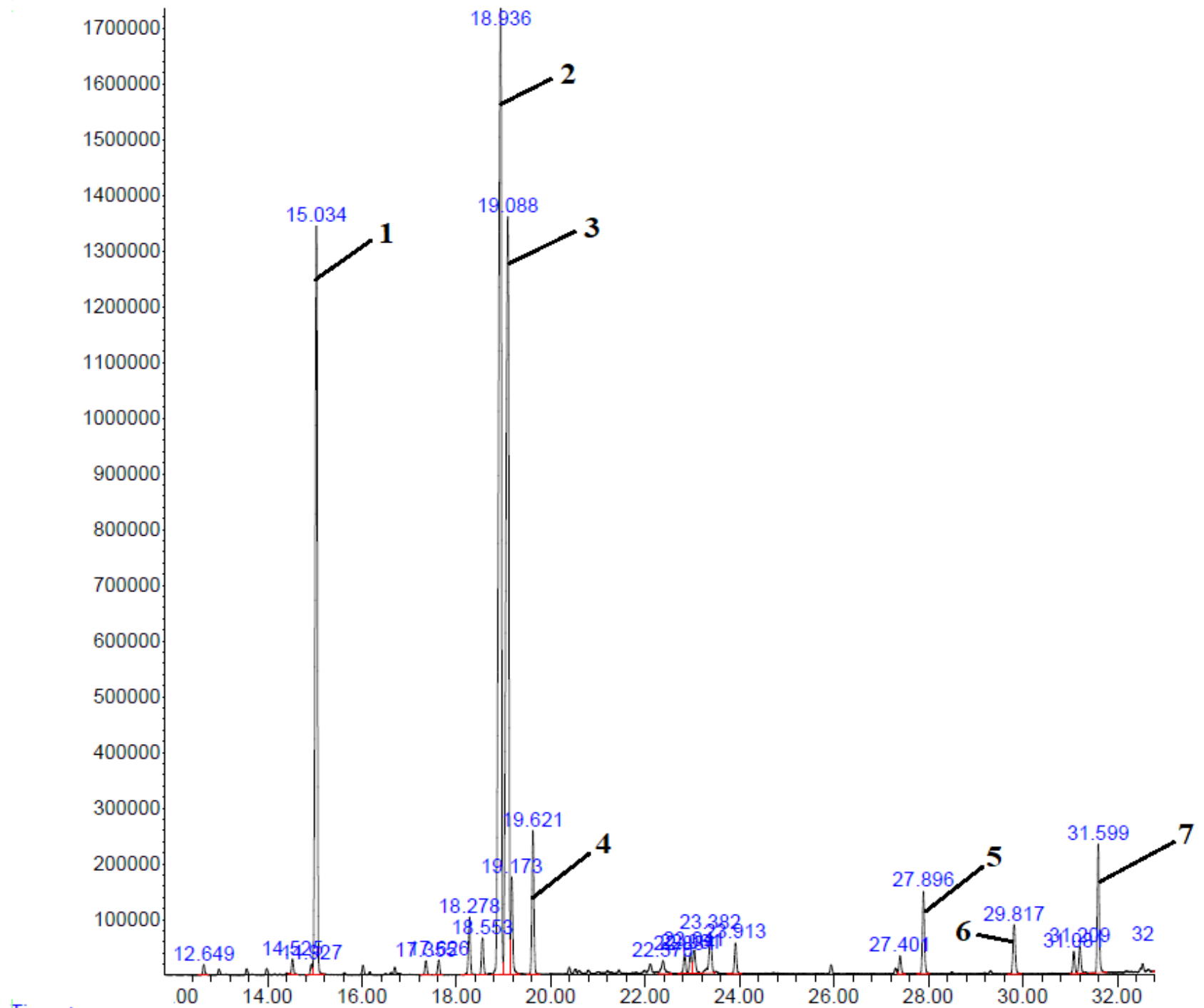

Time-->

Рис. Хроматограма метилових естерів жирних кислот у траві миколайчиків плоских: 1 - пентадеканова кислота, 2 - $\alpha$-ліноленова кислота, 3 - олеїнова кислота, 4 - стеаринова кислота, 5 - бегенова кислота, 6 - трикозанова кислота, 7 - лігноцеринова кислота.

Таким чином у траві миколайчиків плоских визначено комплекс насичених та ненасичених жирних кислот, серед яких є незамінні поліненасичені кислоти, які відіграють важливу роль в біологічних процесах організму.

Висновки. В траві миколайчиків плоских ідентифріковано 7 жирних кислот загальним вмістом
14 477,4 мкг/г, серед яких домінували за кількістю $\alpha$-ліноленова, олеїнова та пентадеканова кислоти.

Конфрлікт інтересів: відсутній.

Conflicts of interest: authors have no conflict of interest to declare.

ISSN 2312-0967. Pharmaceutical review. 2021. № 4 
Фітохімічні дослідження

Phytochemical researches

\title{
RESEARCH OF FATTY ACID COMPOSITION OF HERB ERYNGIUM PLANUM L.
}

\author{
K. V. Gnatoyko, A. R. Grytsyk \\ Ivano-Frankivsk National Medical University \\ dowbeniuk@ukr.net
}

The aim of the work. To study the qualitative and quantitative content of fatty acids in the herb of Eryngium planum L. Materials and Methods. The object of research is the herb of Eryngium planum L., harvested in the summer of 2021 in the village of Pidluzhye, Tysmenytsia district, Ivano-Frankivsk region. Qualitative and quantitative content of fatty acids was determined by gas chromatography with mass spectrometry on a Agilent 6890N/5973inert chromatograph (Agilent technologies, USA).

Results and Discussion. 7 fatty acids (2 unsaturated and 5 saturated) were found and identified in the herb of Eryngium planum L. Quantitatively predominant alpha-linolenic, oleic and pentadecanoic acids (37.6 \%, $29.5 \%$ and $22.1 \%$ respectively). Stearic, behenic, tricosanic, lignoceric acids were also detected, the total amount of which is $10.8 \%$.

Conclusions. The qualitative composition and quantitative content of fatty acids in the herb of Eryngium planum L. were determined during the study. A total of 7 fatty acids were identified, of which alpha-linolenic, oleic and pentadecanoic acids are predominating.

Key words: eryngium planum; fatty acids; gas chromatography; medicinal plants.

\section{Перелік бібліографічних посилань}

1. An update of the Angiosperm Phylogeny Group classification for the orders and families of flowering plants: APG IV. Botanical Journal of the Linnean Society. 2016. Vol. 181, No. 1. P. 1-20. URL: https://doi.org/10.1111/ boj.12385

2. Royal Botanic Gardens, Kew and Missouri Botanical Garden. The Plant List. URL: http://www.theplantlist. org/

3. Ievina B., Rostoks N., Syed N. Genetic diversity and structure of Northern populations of the declining coastal plant Eryngium maritimum. Proceedings of the Latvian Academy of Sciences. Section B. Natural, Exact, and Applied Sciences. 2019. Vol. 73, No. 5. P. 446454. URL: https://doi.org/10.2478/prolas-2019-0008

4. Манюк В. В. Родина селерових (Аріасеае) у фрлорі Орільського національного природного парку. Вісник Дніпропетровського університету. Геологія, географрія. 2016. T. 24, № 1. C. 54. URL: https://doi. org/10.15421/111609

5. Alnaija H., Alkoot H., Alhussaini M. Popularity of herbal medicine. The Medical Journal of Cairo University. 2021. Vol. 89, No. 6. P. 935-943. URL: https://doi. org/10.21608/mjcu.2021.184520

6. Essential Oil Composition of the different parts and in vitro shoot culture of Eryngium planum L. B. Thiem, M. Kikowska, A. Kurowska, D. Kalemba. Molecules. 2011. Vol. 16, No. 8. P. 7115-7124. URL: https://doi. org/10.3390/molecules 16087115

7. Chemical and bioactivity evaluation of Eryngium planum and Cnicus benedictus polyphenolic-rich extracts. G. Paun, E. Neagu, V. Moroeanu et al. BioMed Research International. 2019. Vol. 2019. P. 1-10. URL: https://doi.org/10.1155/2019/3692605

8. щербакова А., Коновалов Д. Изучение полисахаридного комплекса в корнях некоторых видов синеголовника, интродуцированных в условиях предкавказья. Сборник научных трудов ГНБС. 2018. Т. 146, № 1. С. 214-218. URL: https:// doi.org/10.25684

9. Conea S., Vlase L., Chirila I. Comparative study on the polyphenols and pectin of three Eryngium species and their antimicrobial activity. Cellulose Chemistry and Technology. 2016. Vol. 50, No. 3-4. P. 473-481.

10. Derda M., Thiem B., Budzianowski J. The evaluation of the amebicidal activity of Eryngium planum extracts. Acta Poloniae Pharmaceutica. 2013. Vol. 70, No. 6. P. 1027-1034.

11. Effects of Eryngium planum and Eryngium campestre extracts on ligatureinduced rat periodontitis article. S.Conea, A.Pârvu, M.Taulescu, L.Vlase. Digest Journal of Nanomaterials and Biostructures. 2015. Vol. 1, No. 10. P. 693-704.

12. Improvement in long-term memory following chronic administration of Eryngium planum root extract in scopolamine model: Behavioral and molecular study. M. Ozarowski, B. Thiem, P. L. Mikolajczak, A. Piasecka. Evidence-Based Complementary and Alternative Medicine. 2015. Vol. 2015. P. 1-13. URL: https:// doi.org/10.1155/2015/145140

13. Naghshi S. Dietary intake and biomarkers of alpha linolenic acid and risk of all cause, cardiovascular, and cancer mortality: systematic review and dose-response meta-analysis of cohort studies. BMJ. 2021. Vol. 375, No. 2213. P. 1-19. URL: https://doi.org/10.1136/bmj. n2213

14. Karacor K., Cam M. Effects of oleic acid. Medical science and Discovery. 2015. Vol. 2, No. 1. P. 125-132. URL: https://doi.org/10.36472/msd.v2i1.53

ISSN 2312-0967. Фармацевтичний часопис. 2021. № 4 


\section{References}

1. Chase M, Christenhusz M, Fay M, Byng J Judd, W, Soltis D, Mabberley D. An update of the Angiosperm Phylogeny Group classification for the orders and families of flowering plants: APG IV. Botanical Journal of the Linnean Society.2016; 181(1): 1-20. Available from: https://doi.org/10.1111/boj.12385

2. Royal Botanic Gardens, Kew and Missouri Botanica Garden. The Plant List. Available from: http://www.theplantlist.org/

3. levina B, Rostoks N, Syed N. Genetic diversity and structure of Northern populations of the declining coastal plant Eryngium maritimum. Proceedings of the Latvian Academy of Sciences Section B Natural Exact and Applied Sciences. 2019; 73(5): 11-19. Available from: https://doi.org/10.2478/prolas-2019-0008

4. Manyuk VV. [Celery family (Apiaceae) in the flora of the Oryol National Nature Park]. Visnyk Dnipropetrovskoho universytetu. Heolohiia, heohrafiia. 2016; 24(1): 54. Available from: https://doi.org/10.15421/111609

5. Alnajja $\mathrm{H}$, Alkoot $\mathrm{H}$, Alhussaini $\mathrm{M}$. Popularity of herbal medicine. The Medical Journal of Cairo University. 2021;89(6): 935-43. Available from: https://doi. org/10.21608/mjcu.2021.184520

6. Thiem B, Kikowska M, Kurowska A, Kalemba D. Essential oil composition of the different parts and in vitro shoot culture of Eryngium planum L. Molecules.2011;16(8): 7115-24. Available from: https://doi. org/10.3390/molecules16087115

7. Paun G, Neagu E, Moroeanu V, Albu C, Savin S, Lucian Radu G. Chemical and Bioactivity Evaluation of Eryngium planum and Cnicus benedictus Polyphenolic-Rich Extracts. BioMed Research International.2019;3: 1-10. Available from:: https://doi.org/10.1155/2019/3692605
8. Shcherbakova A, Konovalov D. [Study of the polysaccharide complex in the roots of some eryngium species introduced in Ciscaucasia]. Collection of scientific works of GNBS. 2018;146(1): 214-8. Available from: https://doi.org/10.25684. Russian.

9. Conea S, Vlase L, Chirila I. Comparative study on the polyphenols and pectin of three Eryngium species and their antimicrobial activity. Cellulose Chemistry and Technology. 2016;50(3-4): 473-81.

10. Derda M, Thiem B, Budzianowski J. The evaluation of the amebicidal activity of Eryngium planum extracts. Acta Poloniae Pharmaceutica. 2013;70(6): 1027-34.

11. Conea S, Pârvu A, Taulescu M, Vlase L. Effects of Eryngium planum and Eryngium campestre extracts on ligatureinduced rat periodontitis Article. Digest Journal of Nanomaterials and Biostructures. 2015;(10): 693-704.

12. Ozarowski M, Thiem B, Mikolajczak PL, Piasecka A. Improvement in long-term memory following chronic administration of eryngium planum root extract in scopolamine model: Behavioral and Molecular Study. Evidence-Based Complementary and Alternative Medicine; 2015: 1-13. Available from: https://doi. org/10.1155/2015/145140

13. Naghshi S. Dietary intake and biomarkers of alpha linolenic acid and risk of all cause, cardiovascular, and cancer mortality: systematic review and doseresponse meta-analysis of cohort studies. BMJ. 2021;375(2213.): 1-19. Available from: https://doi. org/10.1136/bmj.n2213

14. Karacor K, Cam M. Effects of oleic acid. Medical Science and Discovery. 2015;2(1): 125-132. Available from: https://doi.org/10.36472/msd.v2i1.53

\section{Відомості про авторів}

Грицик А. Р. - д. фрармац. наук, професор, завідувач кафедри фрармацевтичного управління, технології ліків та фрармакогнозії Івано-Франківського національного медичного університету, Івано-Франківськ, Україна. E-mail: grycyk@ukr.net, ORCHID: 0000-0001-7335-887X

Гнатойко К. В. - аспірант кафедри фрармацевтичного управління, технології ліків та фрармакогнозії ІваноФранківського національного медичного університету, Івано-Франківськ, Україна. E-mail: dowbeniuk@ukr.net, ORCHID: 0000-0002-4308-5134

\section{Information about the authors}

Grytsyk A. R. - DSc (Pharmacy), Professor, Head of the Pharmaceutical Management, Drug Technology and Pharmacognosy Department, Ivano-Frankivsk National Medical University, Ivano-Frankivsk, Ukraine. e-mail: grycyk@ukr.net , ORCHID 0000-0001-7335-887X

Gnatoyko K. V. - PhD-student of the Pharmaceutical Management, Drug Technology and Pharmacognosy Department, Ivano-Frankivsk National Medical University, Ivano-Frankivsk, Ukraine. e-mail:dowbeniuk@ukr.net , ORCHID 0000-00024308-5134 